\title{
О ОДНОСУ СЛОГАНА И ФРАЗЕОЛОШКИХ ЈЕДИНИЦА У ПОЛИТИЧКОМ ДИСКУРСУ У СРПСКОМ ЈЕЗИКУ**
}

\begin{abstract}
Предмет овог рада јесте однос између слогана и фразеолошких јединица. Корпус за ово истраживање чине слогани коришћени у изборним кампањама од 1990. до 2016. године. Циљеви овог истраживања јесу: испитати типове односа између слогана и фразеолошких јединица; указати на језичка (пре свега лексичка и морфосинтаксичка) средства којима се фразеолошке јединице дезинтегришу и постају део слогана. Фразеолошке јединице у ширем смислу деле са слоганима три важне карактеристике: сажетост, ефектност и експресивност. Овим општим карактеристикама може се придодати и чињеница да и слогани, као и фразеолошке јединице, постају сведочанство о колективном искуству народа у једном периоду, с тим што фразеолошке јединице имају много ширу намену. Слогане од фразеолошких јединица разликује, пре свега, функција, а затим и структура. Слогани се према фразеолошким јединицама у ширем смислу односе на три начина: целовите фразеолошке јединице постају слогани (1), у слоганима се актуализују и реконтекстуализују поједине фразеолошке јединице или њихови делови (2) и најчешће - фразеолошке јединице се трансформишу различитим лексичким и морфосинтаксичким средствима како би формирале слоган (3).
\end{abstract}

Кључне речи слоган, фразеологизам, политички дискурс

\section{1. Увод}

Плакати представљају специфичан спој језика и слике, језичког и нејезичког, при чему доминанту језичког дела чине слогани. Предмет овог рада јесте однос између слогана и фразеолошких јединица. Полазимо од одређења

\footnotetext{
*s.slijepcevic@gmail.com

** Овај рад је настао у оквиру пројекта 178009 Лингвистичка истраживања савременог српског књижевног језика и израда Речника српскохрватског кьижевног и народног језика САНУ, који у целини финансира Министарство просвете, науке и технолошког развоја Републике Србије.
} 
слогана и специфичних црта овог микрожанра, а затим указујемо на сличности и разлике у односу на фразеолошке јединице у ширем смислу.

Корпус за ово истраживање чине слогани коришћени у изборним кампањама од 1990. до 2016. године. Циљеви овог истраживања јесу: испитати типове односа између слогана и фразеолошких јединица; указати на језичка (пре свега лексичка и морфосинтаксичка) средства којима се фразеолошке јединице дезинтегришу и постају део слогана.

\section{2. Однос слогана и фразеолошке јединице у ширем смислу}

\section{1. Терминолошко питање и преглед селектоване литературе}

Поред термина слоган, употребљавају се, неретко синонимично, још и парола, мото, крилатица, девиза и лозинка (Матић 2010: 7). Како бисмо размотрили опсег значења свих поменутих термина, упоредили смо њихова значења у референтним речницима српског језика.

Слоган се дефинише као „оно што се истиче као основно начело, гесло, девиза" (РМС). Речник страних речи и израза Милана Вујаклије доноси етимологију ове лексеме:

Слоган енг. slogan стари ритмички ратни поклич шкотских горштака; у САД: лозинка, гесло, крилатица (политичка, културна и др.), нпр. „Сваке недеље купи по једну књигу".

У Рјечнику страних ријечи, израза и кратица Братољуба Клаића из 1958. године, поред потврде етимологије, наилазимо и на кратку напомену која се тиче уобичајене стилске црте:

Слоган енгл. (шкотски бојни поклич; парола, лозинка) успјела и привлачна рекламна реченица (обично римована).

Међутим, као што ће анализа и показати, рима свакако није толико заступљена да се може сматрати основном цртом слогана.

Најпотпуније се односом слогана и пароле бавио Зоран Славујевић. Он, наиме, сматра да је слоган у оном смислу у ком га ми данас разумемо новијег датума, али истовремено, позивајући се на етимологију, али и на развој форме, истиче да овај појам није производ савремених друштава, а још мање политичког маркетинга, иако се и сам понајвише бави слоганима из перспективе политичког маркетинга. Наиме, Славујевић претече слогана не види само у ратничким покличима, већ залази дубље у прошлост, наводећи као примере старолатинске речи максима, сентенца и сл., које су се такође односиле на кратке и ефектне форме. На овом месту, важно је истаћи Славујевићеву примедбу насталу поређењем лексичке дефиниције слогана и терминолошке дефиниције, важне за одређену струку: 
„У савременом енглеском говору slogan означава реч или реченицу која се користи да изрази карактеристичну позицију става или циља коме се стреми, а у маркетиншком жаргону означава кратку, ударну реченицу која се користи у рекламирању и промотивним активностима. Французи користе такође енглеску реч slogan у значењу кратке и упадљиве пропагандне сентенце, будући да француска реч parole има значење 'реч уопште, али и обећање'. Код нас реч слоган изједначава се са речју 'парола' (етимолошки корен је франц. реч parole), а има значење и бојног поклича, гесла, начела, девизе. У руском језику користи се реч 'парола' и има значење слогана" (Славујевић 2007: 153).

Славујевић скреће пажњу на покушаје да се разграниче слогани од парола, али истовремено одбацује ово разграничавање као неосновано наводећи репрезентативне примере који побијају овакво становиште:

„Одређење слогана као исказа који експлицитно носи позитивне садржаје, а пароле као исказа негативног садржаја не одговара ни значењима која ови појмови имају у језицима из којих потичу, нити значењима у којима се користе у стручној литератури и у свакодневном говору. На пример, без обзира какав однос имали према револуцијама уопште, па и према француској буржоаској револуцији, парола Liberté, fraternité, egalité, која је била на њеном барјаку, која је исказивала њене основне циљеве, не представља негативан исказ, као што негативан исказ не садржи ни чувена парола радничког покрета Пролетери свих земаља, уједините се. Ако се још примети да слоган, односно парола може да садржи и позитиван и негативан исказ (на пример, један од слогана НОБ-а био је Смрт фашизму, слобода народу) и још даље, да сваки експлицитни исказ 'за' истовремено, мада имплицитно, индиректно, има значење и 'против нечега', онда овакво разликовање појмова слоган и парола нема оправдања" (Исто).

Овакву Славујевићеву тврдњу поткрепљују и дефиниције лексеме парола у речницима српског језика. Према Речнику српскога језика Матице српске парола има два значења, од којих је за нас значајно примарно:

1. а. реч, реченица, слоган пропагандног, манифестационог садржаја који јавним узвикивањем или исписивањем на таблама, транспарентима и сл. исказује какав општи (обично политички) став, захтев и сл. б. фиг. (обично у множини) овештали израз, мисао, фраза без духа и оригиналности, празне бесадржајне речи.

2. в. лозинка (1. а).

Вујаклијин речник доноси потврде о етимологији ове лексеме:

Парола (фр. parole; тал. parola; л. parabola) првобитно: поучна изрека; затим: реч, говор, обећање, часна реч; вој. реч која служи за распознавање, лозинка.

Клаићев речник уз дефиницију „лозинка, гесло, крилатица”, доноси и додатак о форми и карактеру: „сажета реченица пропагандног карактера”.

Веома су сличне дефиниције које Речник српскога језика Матице српске даје за бохемизам гесло и реч романског порекла девиза:

Гесло с чеш. кратка изрека која служи као руководећа идеја, основно начело у нечему, девиза, мото.

Девиза ж фр. сажето изражена мисао која служи као руководеће начело, гесло, крилатица.

Речник страних речи и израза Милана Вујаклије, међутим, доноси погрешну етимологију, а општијем значењу придодаје и специфично значење изреке која се користи на грбу и застави:

Девиза (шп. devisa) лозинка, гесло, начело; кратка изрека на грбу, застави. 
У Речнику српскога језика Матице српске мото се дефинише као књижевни термин:

Мото посебна, индикативна мисао, изрека, пословица, цитат или сл. испред почетка неког списа, расправе, књижевног дела као наговештај његове основне идеје, побуде или опредељења.

С друге стране, Вујаклија и Клаић у први план стављају језгровити карактер, и то:

Вујаклија:

Мото (од лат. muttire: зуцнути, зуцкати) језгровита мисао, пословица или навод (цитат).

Кланћ:

Мото 1. оштроумна, духовита изрека.

2. кратки натпис на почетку књиге или поглавља; гесло, лозинка, епиграф који укратко наговјешћује смисао онога што слиједи.

Судећи и према општој употреби и према распрострањености и према речничкој дефиницији, па и према етимологији, за означавање порука у политичким плакатима најчешће користимо термин слоган $(u)$. Најпотпуније одређење слогана даје Славујевић:

„Политички, односно изборни слогани најчешће се одређују као синтетизоване, кратке и атрактивне поруке које пласирају партије и кандидати да би публици презентовали, учинили схватљивим и прихватљивим своје кључне политичке садржаје, односно садржаје са којима наступају у кампањи. Презентовање широј публици програмских ставова и изборних обећања странака и кандидата не може бити успешно ако они нису преточени у кратке и сажете, лако памтљиве, допадљиве и, најзад, прихватљиве поруке-слогане” (Славујевић 2007: 153-154).

Славујевић оваквим одређењем сажима све основне одлике слогана као вербалног дела плаката у рекламно-пропагандном жанру у политичком дискурсу: сажетост (синтетизоване, кратке), експресивност (атрактивне поруке, допадљиве, лако памтљиве), пропагандни карактер и убеђивачки циљ (да би публици презентовали, учинили схватљивим и прихватљивим своје кључне политичке садржаје итд.), одакле и важна одлика- усмереност на реципијента (слогани-поруке).

Бавећи се маркетиншким аспектом слогана, Славујевић примећује да слогани исказују оне елементе идентитета које партија или кандидат желе да учине препознатљивим и прихваћеним елементима свог имиџа и позиционирања у вишедимензионалном простору партијске сцене, али и да исказују политичке циљеве којима желе да појачају мотивацију присталица за одређени политички ангажман и да их мобилишу у конкретним политичким акцијама (Славујевић 2007: 154). Славујевић иде и корак даље у разматрању појма слогана, уводећи међу његове карактеристике и оне психолошког типа:

„На овој карактеристици (сажетост) слогана посебно инсистира Д. Викторов. Он повезује слоган са појмовима психичко економисање и уштеда, на трагу Фројдовог рада 'досетка и њене везе с несвесним', који се заснива на основном ставу да свака уштеда 
напора, духовног и мишићног, изазива код човека задовољство, при чему се ово економисање односи како на саму суштину, тако и на форму. Када је реч о суштини, Викторов интерпретира Фројда у смислу да се ради о задовољству које проистиче из ублажавања цензуре коју разум врши над нашим когнитивним процесима или уз ублажавања цензуре коју морал чини над нашим нагоном. Када је, пак, реч о форми, Викторов наводи читав низ 'техника економисања' које је идентификовао Фројд: кондензовање, употреба истог говорног материјала, двоструки смисао, грешке у расуђивању, представљања помоћу супротности, обједињавања, алузије, изостављање итд." (Славујевић 2007: 153).

Бирд примећује да су слогани формирани тако да привуку пажњу, али и да натерају реципијенте да мисле. Најчешће се то чини различитим играма речи и поигравањима са значењем. Бирд подвлачи да се понекад користи само једна реч којом се показује позитиван став читавог рада партије будући да су слогани углавном начињени тако да привуку пажњу различитих циљних група и да их истовремено подстакну на деловање (Бирд 1999: 58).

Поред слогана, битни су, јер се паралелно појављују, и контраслогани. Контраслоган представља одговор на постојећи слоган конкуренције у изборној кампањи. Ефектност се у контраслоганима, заправо, заснива на инверзији речи и слогана опонента или неки други тип деконструкције постојећег слогана којом се мења и значење слогана-мотиватора.

\section{2. Сличности и разлике између слогана и фразеолошких јединицุа у ширем смислу}

Слогани су, због карактеристичне експресивности и сажетости, с једне стране, слични фразеолошким јединицама, а с друге стране, слободније су форме и структурно су отворени за интегрисање читавих фразеологизама, као и за њихову модификацију.

Фразеолошке јединице се најчешће дефинишу као изразито експресивни вишелексемни спојеви, целовитог и релативно устаљеног лексичког састава. У овом раду у обзир узимамо фразеолошке јединице у ширем смислу, дакле, у оном смислу у ком их узимају Мелерович и Мокијенко (Мелерович/Мокијенко 2008: 83), када под фразеолошким јединицама сматрају и устаљене изразе, називе филмова, књижевних и других уметничких дела, фразе народно-разговорног карактера, реплике из филмова, реклама, представа итд.

Фразеологизми у ширем смислу, дакле, обухватају и максиме, афоризме, пословице. Диференцирајући пословице у односу на остале микрожанрове, Јелена Јовановић истиче да пословице могу изражавати уопштена, безвременска, општељудска и општеприхваћена запажања, али и искуства и коментаре појединих историјских раздобља, друштвених средина и заједница (Јовановић 2006: 14), а као разликовну црту издваја „чист народни језик” (Јовановић 2006: 15). Управо је народни језик кључан за обраћање што широј публици, њиме се политичари приближавају бирачима, зато што своја обраћања саображавају језику који је лако разумљив. Још једна основа за коришћење пословица, и уопште фраза разговорног и народног карактера, тиче се и очувања традиције и колективних архетипа који су свој језички облик 
добили у овим формама: „То су језичке творевине које не настају из индивидуалних побуда, него су израз колективне друштвене духовне делатности. Чим је таква духовна делатност усмерена на онај део људскога света који је за њ од основне важности, она налази изражаја у језику, згушњавајући га у одређене структурне целине, управо у те једноставније форме” (Јовановић 2006: 23).

\section{3. Анализа}

У слоганима се фразеолошке јединице јављају на три начина: преузимају се целе фразеолошке јединице, актуелизују се и реконтекстуализују различитим језичким средствима, трансформишу се различитим језичким средствима.

У једној изборној кампањи јавиле су се целовите пословице, претходно најављене крилатицом Ко што народ каже: Кућа се од темеља гради. Правда је снага над силом. Ни по бабу ни по стричевима. Трипут мери, једном сеци. Како сејеш, тако ћеш и пожнети. Како народ каже - јасно ко дан. Коштуница (избори 2000). Оваква врста кампање вероватно је циљала на промовисање лидера кроз народне мудрости. Позивањем на колективно искуство прокламоване су вредности које би требало да буду заједничке народу и политичком кандидату.

\section{II}

Приметно је да се најчешће јављају фразеологизми са компонентом реч: Ми држимо реч. (избори 1992); Поштоваћемо дату реч; Коштуница. Дајем реч. (избори 2000); Ја држим реч (избори 2002); Реч је реч. Човек се по речи познаје (избори 2003); Дела говоре више од речи (избори 2012). Оваква фреквентност може се објаснити тиме што лексема реч у овим конструкцијама углавном има значење обећаға или дате обавезе (8. значење у РМС). Такође, примећује се да су ови фразеологизми конкретизовани на временско-модалном плану, те се тако формирају слогани актуелизацијом фразеологизама (перформативни глаголи налазе се у презенту и формирају исказе с комисивном функцијом ${ }^{1}$ Дајем реч, Ми држимо реч, како би се постигла убедљивост), а када се субјекти јављају, углавном су реализовани једном од двеју најфреквентнијих заменица у политичком дискурсу: ја и ми.

\footnotetext{
1 „Искази с комисивном функцијом (обећање, заклетва, опклада). - Такви искази садрже интенцију говорног лица да јамчи за свој будући акциони или вербални чин који је, по правилу, у интересу адресата" (Тошовић 2005: 997).
} 
У овој врсти слогана, ревитализованим фразеологизмима постиже се везивање за актуелни друштевно-политички контекст, много чешће, заправо, за лидера изборне кампање као промотера општенародних вредности, што је омогућено дијалогичношћу с изворним фразеологизмом.

Највећи број фразеологизама у слоганима претрпи трансформације на више језичких нивоа.

Слогани који садрже фразе разговорног карактера углавном су мотивациони и подстрекачки: Један за све (избори 1997); Сачувајте образ! // Да Србији крене! // Судбина у твојим рукама (избори 2000); Србија на 1. месту // Да нам сване (избори 2003). Поједини фразеологизми су контраховани: од фразе Сви за једног, један за све начињен је слоган Један за све; од имати судбину у својим рукама начињен је слоган Судбина у твојим рукама.

Слоган Сачувајте образ добијен је морфолошко-творбеном трансформацијом - од конструкције са глаголом несвршеног вида чувати образ створена је конструкција са перфективним глаголом, са наглашеним резултативним значењем. Милан Шипка примећује да израз чувати образ са значењем „чувати / очувати / спасити част / углед” наводи само Матешићев речник, док се у нашим општим речницима не спомиње, иако потврда постоји у Његошевом Горском вијениу (Шипка 2008: 563):

Отпиши му како знаш, владико, и чувај му образ ка он теби!

Шипка наводи да се пренесено значење лексеме образ развило у процесу фразеологизације, те је захваљујући фразеологизмима ова лексема постала синоним за моралне вредности, као што су част, поштење, понос (Шипка 2008: 566), што свакако обезбеђује јак убеђивачки потенцијал када се употребљава у изборним кампањама. Такође, концептуални приступ Ане Пејановић читавом систему фразеологизама с компонентом образ показује постојање два опозитна низа када је реч о етничком упливу: „У једном се низу налазе оне фразеолошке јединице која одржавају друштвено прихватљиво, пожељно понашање, идеал, оно за шта народ каже 'ваља се'. Други пак низ садржи јединице супротне семантике, а оне су одраз непожељног, неприхватљивог, анатемисаног, онога за шта народ каже 'не ваља се'. Први се кодекс понашања кроз језик 'препоручује' благословима, док се други 'осуђује' клетвама" (Пејановић 2009: 410). Ово опажање важно је када се има у виду императивни тон у слогану Сачувајте образ, будући да тако интониран упућује на опомену, пре него на препоруку, при чему садржи и елементе фине претње, имајући у виду оба пола етичког концепта. 
Издвајају се и слогани у којима се јављају фразеологизми чијој је трансформацији допринела негација ${ }^{2}$, која, заправо, служи истовремено и као афирмација промена. Слоган Није на продају формиран је од изјавно-одричне реченице (то су реченице с општом или посебном негацијом (Пипер и др. 2005: 967), а у конкретном примеру она је мотивисана фразом бити на продаjy). Од ове врсте реченица сачињен је и слоган Нећу опет да гледам исти филм. Слоган Да не бере онај који не сади! формиран је од заповедно-одричне реченице, којом се изражава императивна прохибитивност (Пипер и др. 2005: 969), а она је овде реализована конструкцијом $\partial a+$ презент несвршеног глагола (о изражавању императивности још и у: Ивић 1958; Танасић 2005). Посебан је случај негирање у напоредном односу дуплицираним одричним везником ни у следећем фразеологизму: Ни лево, ни десно. Фразеологизам лево и десно, према РСАНУ, има значење „на све стране, где год се стигне, тамо-амо", синонимично с фразеологизмом лево-десно, а негираним обликом сужава се значење и блокира могућност избора.

Занимљив пример дезинтеграције фразеолошке јединице у ширем смислу, прецизније, читаве народне пословице представља слоган Ми немамо свијетло оружје, ал' имамо срие у јунака (избори 2016). Наиме, у овом примеру лексички састав је мање-више очуван (оригинална пословица гласи Бој не бије свијетло оружје, већ бој бије срие у јунака), међутим, распоред експликаторних компонената је другачији, а изостављен је концепт битке, макар привидно (лексеме бој и бити су изостављене, али је лексема јунак остала). Семантичко тежиште остаје - слоганом се циља на концепт храбрости и части, који се заснива на јуначком срцу. Контрастрираност између оружја и срца је, такође, задржана, с тим што је у слогану реализована супротним везником али (скраћено ал').

\section{4. Закључак}

Фразеолошке јединице у ширем смислу деле са слоганима три важне карактеристике: сажетост, ефектност и експресивност. Овим општим карактеристикама може се придодати и чињеница да и слогани, као и фразеолошке јединице, постају сведочанство о колективном искуству народа у једном периоду. Међутим, разликује их, пре свега, функција, а затим и структура.

Слогани се према фразеолошким јединицама у ширем смислу односе на три начина: целовите фразеолошке јединице постају слогани (1), у слоганима се актуализују и реконтекстуализују поједине фразеолошке јединице или њихови делови (2) и најчешће - фразеолошке јединице се трансформишу различитим лексичким и граматичким средствима како би формирале слоган

\footnotetext{
${ }^{2}$ Под негацијом подразумевамо семантичку категорију која се на синтаксичком нивоу типично исказује одричним реченицама, али се лексички исказује и одричним заменицама (нико, ништа), одричним заменичким прилозима (нигде, никако) и сл. (Пипер и др. 2005: 963).
} 
(3). Стилске и прагматичке последице могу бити различите: показује се дијалогичност, а некад се изражава иронија, полемише се са прототекстом итд.

Фразеологизми у ширем и ужем смислу у слоганима најчешће подлежу трансформацији како би се њихова употреба политизовала у датом тренутку и тиме добила јачи убеђивачки карактер. Непредвиђеност индивидуалних асоцијација и начина да се вербално изразе заснива се на различитим екстралингвистичким факторима одговорним за мотивацију и условљеним углавно социјално-политичком ситуацијом, особинама стереотипног схватања света, али и стваралачким потенцијалом говорника. Фразеолошке јединце у слоганима пролазе различите процесе трансформације ${ }^{3}$, од којих су најчешће замена лексема, редукција, употреба другачијих морфо-синтаксичких облика, комбинација неких или свих поменутих варијација, контаминација и сл.

\section{РЕЧНИЦИ}

Вујаклија: Милан Вујаклија, Лексикон страних речи и израза, Београд: Просвета, 1976.

JM: Josip Matešić, Frazeološki rječnik hrvatskoga ili srpskoga jezika, Zagreb: Školska knjiga, 1982.

Клаић: Bratoljub Klaić, Rječnik stranih riječi, izraza i kratica, Zagreb: 1962.

PКТ: Речник књижевних термина, Институт за књижевност и уметност у Београду, Београд: Нолит, 1986.

PMC: Речник српскога језика, Нови Сад: Матица српска, 2007.

РСАНУ: Речник српскохрватског књижевног и народног језика САНУ, књ. I-XIX, Београд: Институт за српски језик, САНУ, 1959-2014.

Ш-К: Милан Шипка, Иван Клајн, Велики речник страних речи и израза, Нови Сад: Прометеј, 2012.

\section{ЛИТЕРАТУРА}

Бирд 1999: Adrian Beard, The Language of Politics (Intertext), London: Routledge. Ивић 1958: Милка Ивић, „Словенски императив уз негацију”, Радови X/ Научно друштво НР Босне и Херцеговине, књ. 4, Сарајево.

Јовановић 2006: Јелена Јовановић, Српске народне пословицее (књ. I и II), Београд: Научно друштво за неговање и проучавање српског језика.

\footnotetext{
${ }^{3} \mathrm{O}$ трансформацији фразеологизама као последици контекста, Марина Катнић-Бакаршић каже да се као посебан случај издваја фраза која се трансформише на неки начин тако да одговара смислу текста. Она том приликом наводи пример: до последњег гласа уместо до последњег даха и указује на стилске последице: „Овакав метатекстуални поступак показује дијалогичност текста са неким другим текстом, а негде је његова функција чисто орнаментална, док другде има функцију изражавања ироније, комике, полемике са прототекстом (текстом изворником)" (Катнић-Бакаршић 1999: 60).
} 
Катнић-Бакаршић 1999: Marina Katnić-Bakaršić, Lingvistička stilistika, Sarajevo: Naučna i univerzitetska knjiga.

Кликовац 2009: Душка Кликовац, „О презенту несвршених глагола за означавање будућих ситуација", Научни састанак слависта у Вукове дане, 38/1, 57-71.

Матић 2010: Томислав Матић, Анализа језика политичких слогана, мастер рад, Београд: Филолошки факултет.

Мелерович/Мокијенко 2008: А. М. Мелерович, В. М. Мокиенко, Семантическая структура фразеологических единиц современного русского языка, Кострома.

Пејановић 2009: Ана Пејановић, „Концептуални статус лексеме образ у српској фразеологији", Научни састанак слависта у Вукове дане, 39/1, 405-415.

Пипер и др. 2005: Предраг Пипер и др., Синтакса савременога српског језика: проста реченица (ред. Милка Ивић), Београд: Институт за српски језик САНУ, Београдска књига - Нови Сад: Матица српска.

Славујевић 2007: Zoran Slavujević, Izborne kampanje: pohod na birače: slučaj Srbije od 1990. do 2007. godine, Beograd: Friedrich Ebert Stiftung: Fakultet političkih nauka: Institut društvenih nauka.

Танасић 2005: Срето Танасић, Синтаксичке теме, Београд: Београдска књига.

Тошовић 2002: Бранко Тошовић, Функиионални стилови, Београд: Београдска књига.

Шипка 2008: Милан Шипка, „Фраземи с лексемом „образ””, Јужнословенски филолог, LXIV, 561-569.

Svetlana Slijepčević

ABOUT THE RELATION BETWEEN SLOGANS AND PHRASEOLOGICAL UNITS

Summary

The subject of our paper is the relation between slogans and phraseological units. The corpora for this research represents slogans for election campaigns for Serbian elections since 1990 till 2016. The aims of the research are: (1) to examine types of relations between slogans and phraseological units, and (2) to indicate various lexical and morpho-syntaxic means which allow phraseological units to disintegrate and become part of political slogans.

Key words: slogan, phraseological unit, political discourse. 